\title{
Association of annual hormonal profile with gonad maturity of mahseer (Tor tambroides) in captivity.
}

\begin{abstract}
Annual gonad hormonal profile of wild, matured mahseer (29 males and 23 female) averaging in weight between $0.95 \pm 0.26$ and $1.19 \pm 0.23 \mathrm{~kg}$ for males and females, respectively, were investigated from November 2007 to November 2008 using enzymelinked immunosorbent assay (ELISA) technique. Blood was collected from caudal vein, monthly and plasma separation by centrifugation was done to measure reproductive hormones: 17 $\beta$-estradiol (E2), testosterone (T), and 11-keto-testosterone (11KT). Gonads were sampled for histology processing to observe their maturity. Highest $\mathrm{T}$ level in females and males was recorded at $0.22 \pm 0.016$ and $0.88 \pm 0.014 \mathrm{ng} / \mathrm{ml}$, respectively. The $11 \mathrm{KT}$ showed several peaks and the highest value was noted at $0.7 \pm 0.018 \mathrm{ng} / \mathrm{ml}$ in November 2008. The female E2 initially was at $1.48 \pm 0.16 \mathrm{ng} / \mathrm{ml}$ and significantly increased $(\mathrm{P}<0.05)$ to $1.53 \pm 0.39 \mathrm{ng} / \mathrm{ml}$ in November 2008. Ovaries were laden with oocytes in several stages in all the samples while testes gonad showed a high level of spermatids throughout the year. Changes in plasma level of the gonadal hormones were correlated with the ovarian and testes maturities. In conclusion, the study suggests that mahseer can be categorized as asynchronized and multiple spawner. The information gathered is important for appropriate breeding and conservation programs of the Malaysian mahseer.
\end{abstract}

Keyword: Mahseer; Gonadal hormone profile; 17 $\beta$-Estradiol; 11-Keto-testosterone; Testosterone; Gonad maturity. 